\title{
Teaching
Anthropology
}

2022, Vol. 11, No. 1, pp. 36-40.

\section{Social order: A neglected aspect of Brian Street's work on literacy}

\author{
Mostafa Hasrati, Ph.D. \\ International Foundation Program, University of Toronto.
}

\section{Introduction}

This manuscript is a personal note to commemorate Brian Street and his legacy in education and most specifically in literacy. I acted as a respondent in the $4^{\text {th }}$ Brian Street's Memorial Event, entitled Decolonising Literacy, organised jointly by the British Association for Literacy in Development and UNESCO Chair in Adult Literacy and Learning for Social Transformation on November $18^{\text {th }}, 2020$. Before I give an account of the three papers presented in this event and explain why Brian's work is still relevant, I would like to introduce Brian Street as I knew him.

I started my PhD with Brian Street in October 1999 at King's College London. I had always been fascinated by language, literacy, social studies, anthropology, ethnography and culture, but it was a totally different experience working with one of the icons in these areas. Prior to my PhD work, I used to work as an Applied Linguistics lecturer at Razi University in Iran, an academic habitus with its own particular features. For instance, it was quite usual for students to approach professors in corridors to ask them questions or engage them in academic discussions. With this assumption, I approached Brian in the very first week of my PhD work in the corridor on his way to his office. He explained to me in a warm and welcoming manner that I could book an appointment to see him in his office.

Empathy was a quality that Brian had to a large extent, exemplified by my experience below. Brian organised a seminar on Wednesdays, where graduate students presented their work and received feedback. In one of my presentations in my first year as a PhD student, a faculty member gave me some harsh criticism, which was a bit out of the ordinary. I did not say anything, but Brian brought this up in our next one-on-one meeting and wanted to see how I felt about it. I opened up to him and suggested that I would prefer more constructive criticisms on my work to further improve my research. He said he would discuss this with that faculty member, and from that time on I vividly experienced a more welcoming and accepting approach from that member of faculty, and in fact we became very good friends. This experience of mine is just an example of how Brian supported his students, not just cognitively but also emotionally.

Brian was one of the most organised people I have seen. Our protocol was that I submit to him my reports in hard copy around one week prior to our supervision meetings. Then on the day of our meeting, he would go through his comments written in the margins of my report. At the end of the meeting, I would once again go through his written comments, which were plenty, and respond to his feedback on my work. Never once did I have a feeling that Brian had not given enough time and attention to my work.

A desire to understand the world from different perspectives was another of Brian's qualities. I was jointly supervised by Brian and Peter Skehan, and we often met to discuss my reports and progress. Peter came from a more positivistic background while Brian was more inclined towards hermeneutics. Each supervision meeting was imbued with both positivistic ideas from Peter (e.g. reliability of my findings; employing grounded theory) and Brian's more interpretivistic approach (e.g. drawing themes from interviews; synthesizing my interpretations of data with theory). It was apparent that both Brian and Peter's epistemological positions converged during our meetings. This, however, was more of an opportunity for me rather than a hindrance, as both Brian and Peter were open to ideas and practices that were not fully in line with their epistemological standpoints.

Last but not least, Brian continued his friendship with his students long after their graduation. I know this through personal communication with some of his previous students. His last contacts with me were a series of emails we exchanged in May 2014 where he shared a set of stories he had written based on his field work in an Iranian village in the 1970s. The preface to the book showed that he was going to publish the ethnographic stories in a book entitled 'Sketches of an Iranian Village', including 14 stories. He sent me five of the stories, 
where they revolved around various characters engaged in literacy and numeracy practices in everyday life in the village and in school. One of the characters, Parviz Khorosani, was from the Education Corp, which was a mass literacy project under the late Mohammad Reza Shah Pahlavi's government. In one of the stories, Parviz came to discover how literacy was part and parcel of everyday village life that villagers practiced, while the school syllabus was far from everyday realities and needs of the villagers. The main theme in all the stories was the disjunction between the prescribed literacy syllabus and the everyday literacy needs of the villagers, a theme that was dominant in Brian's work. As we will see later in this manuscript, this is still a big concern for educators who presented in his $4^{\text {th }}$ Memorial Event on November 18 $8^{\text {th }}, 2020$. The following picture is an original version of one of the stories dated September 13, 1977:

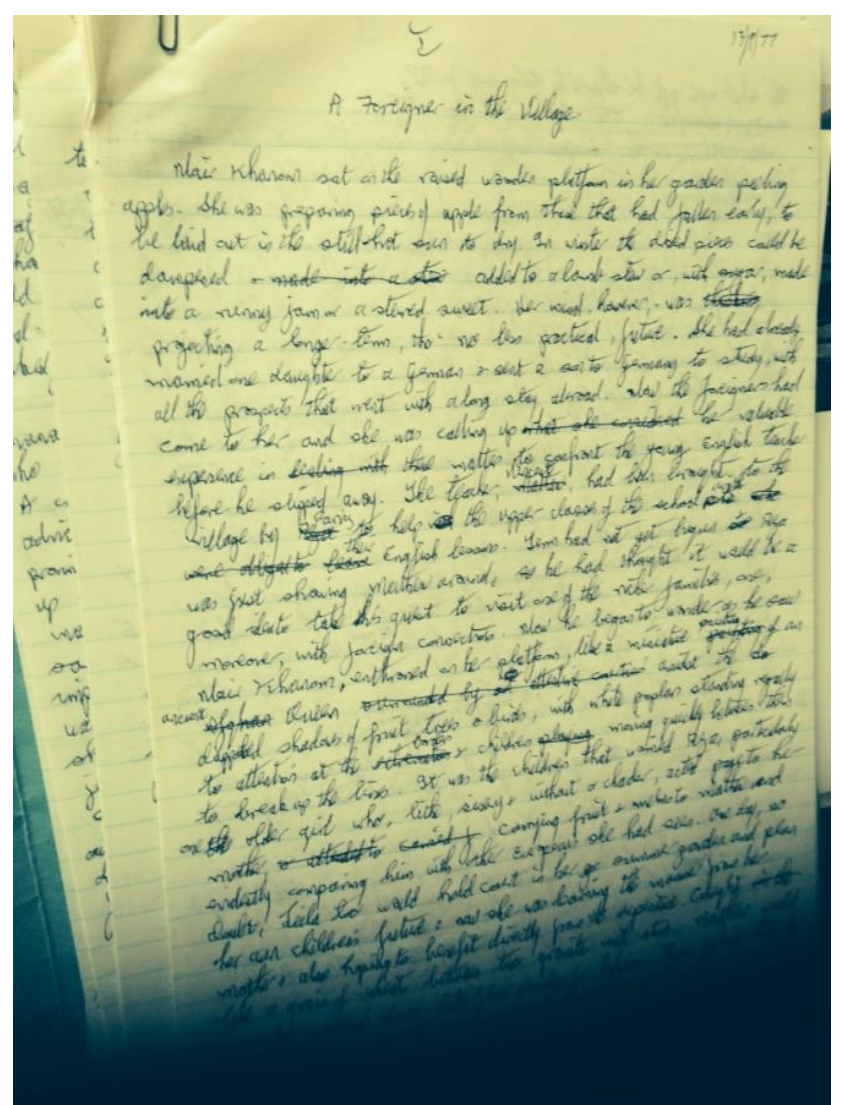

Figure 1: Original written version of one of the stories (Brian Street, email communication, May 2014)

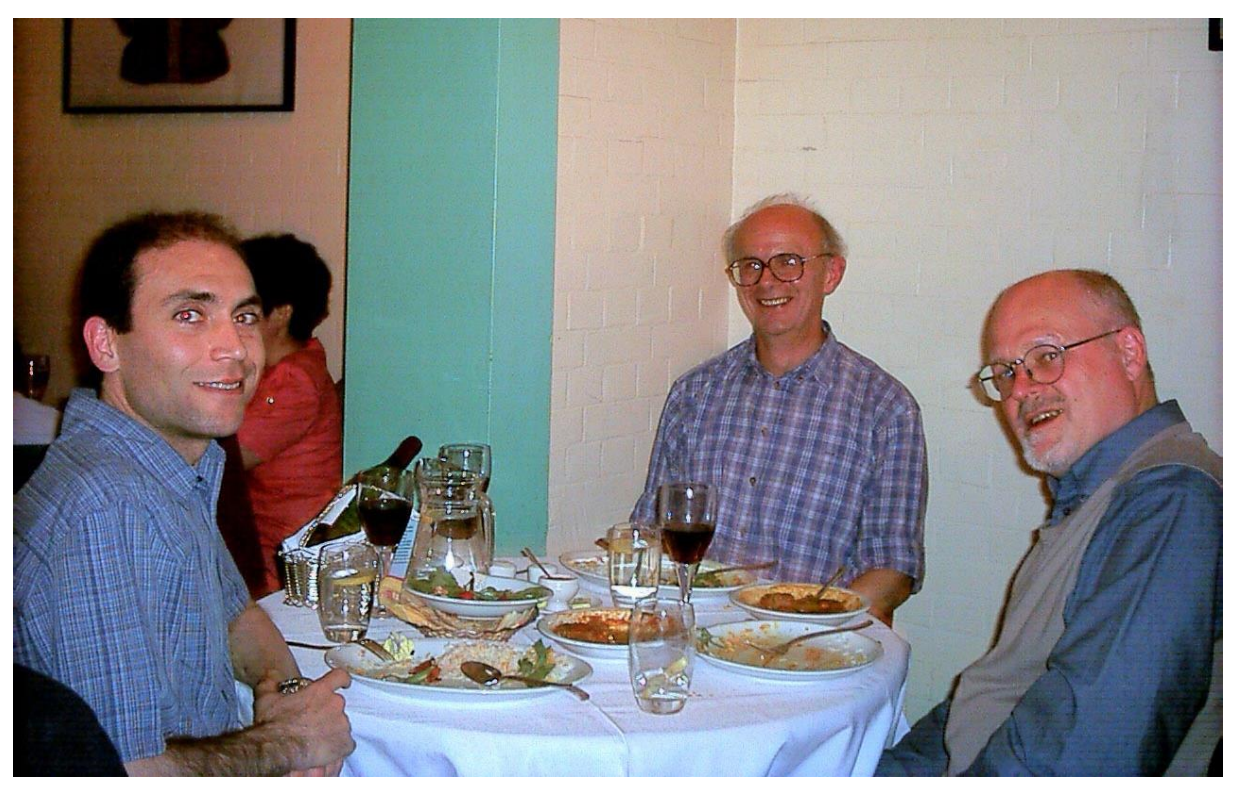

Figure 2: May 12, 2003 (From right to left: Professor Brian Street, Professor Peter Skehan, Author) 


\section{A Summary of Papers Presented at Brian's 4th Memorial Event}

The $4^{\text {th }}$ Brian Street Memorial Event on the theme 'decolonising literacy'was hosted jointly by BALID (British Association for Literacy in Development) and the UNESCO Chair in Adult Literacy and Learning for Social Transformation, on the $18^{\text {th }}$ Nov 2020. In this event, three papers were presented, which I will draw upon as a point of departure to argue that Brian's work is still relevant today:

1. “Literacy for conformity: When local literacies don't count?" by Ahmmardouh Mjaya.

2. "Who owns the text? The interpretative prerogative in adult literacy" by Hélène Boëthius.

3. "Texts in contexts: Speaking 'literacy' to power" by Malini Ghose.

First, I will refer to some key themes in the papers by further linking them with my interpretations of some of Brian's contributions to the field of literacy. I will draw on my experience working with him as my $\mathrm{PhD}$ supervisor from 1999-2003, which was followed by a couple of collaborations leading to some joint publications, and frequent email exchanges.

A common theme in Ahmmardouh's and Helene's presentations was the emphasis on how literacy is intertwined with power relations, a clear distinction between 'us' - literacy experts and policy makers - versus 'them' - the masses who need to develop literacy. Ahmmardouh explained how the National Adult Literacy Programme (NALP) in Malawi defines literacy from a top-down perspective, while there is often a disjunction between people's real literacy needs and experts' perceptions of these needs. Helene, likewise, argued that the production of texts to be used for literacy projects are often the prerogative of experts without factoring in the needs of the participants. She further argued that participants should be empowered to define what counts as literacy and how to approach literacy problems. Going back to the 'us' versus 'them' distinction, it seems that both Ahmmardouh's and Helene's contributions reflect Brian's 'autonomous' and 'ideological' models of literacy (Street, 1984). The autonomous model is very much based on categorizing 'us' - usually western experts - who should define and export literacy to 'them' - often masses of illiterate people. The ideological model, however, conceives of literacy as social practice woven into the social fabric, situated in dynamic relationships with power struggles and epistemological positionings. Needless to say, Brian's approach to improve literacy is moving away from the autonomous model to the ideological model, from a focus on 'us' versus 'them' to an inclusive 'we', where experts and participants come together to jointly define literacy and facilitate its acquisition. These themes seemed to be the common thread in Ahmmardouh's and Helene's presentations.

Malini's presentation drew on her joint 'Letter Project' with Brian, where they tried to train literacy practitioners in Lalitpur to reveal hidden literacy practices to participants. Malini's recent observations, however, show that these practitioners, far from the training they received, have been forced to further conceal the agenda of policy makers and power holders. This reminds me of my joint projects and interactions with Brian, both one-on-one and in Wednesday seminars at King's College London, where we discussed how Bourdieu's social theories could be used alongside new literacy studies to further investigate literacy. More specifically, the situation Malini describes can be categorized as 'symbolic violence' and 'misrecognition', which Bourdieu defines as 'recognition [of domination] as legitimate' (Bourdieu, 1991, p. 140). In Malini's observation, it seems that the domination of policy holders has superseded the practitioners' training to reveal hidden literacy ideologies defined and imposed by policy holders. I assume this is where Brian's work on literacy could be extended to enlighten not only the masses and practitioners but also policy holders and government officials like Mohammad Yasin, another respondent in Brian's memorial event, who can bridge the gap between power-holders and literacy practitioners.

\section{Brian Street's Legacy in Literacy}

In a later work, Brian Street and Adam Lefstein (2007) underlined three approaches to literacy: literacy acquisition, consequences of literacy, and literacy as social practice. The first approach basically deals with how reading and writing are acquired by children, ranging from 'phonic' principles (Adams, 1993) to 'reading for meaning' (Goodman, 1996). The second approach conceives of literacy as a set of skills that will ultimately lead to cognitive consequences for the literates. In other words, the literates are assumed to be more cognitively capable than the illiterates. This approach to literacy is mainly associated with Goody (1977), and still resonates with much of the literacy debates in both developed and developing countries. The third approach, i.e. literacy as social practice, is basically where Brian's work can be located. Drawing on previous research (e.g. Scribner \& Cole, 1978), Brian came up with his famous distinction between the autonomous and ideological models of literacy. Brian challenged the conception that literacy is an autonomous variable that can lead to 'progress, 
civilisation, individual liberty, and social mobility' (p. 116). Instead, he argued that literacy is in fact embedded in the social fabric of any society, and does not necessary lead to all the 'good' qualities attributed to it.

An important aspect of Brian's distinction between the autonomous and the ideological models of literacy, which has often gone unnoticed, is his belief that the qualities attributed to literacy, are in fact characteristics of the 'social order' where literacy is practiced. Such social order, as Brian suggests, could be 'religious and political ideology in ... societies' (Street \& Lefstein, 2007, p. 119). This basically means if a nation is developed, it is not due to literacy, but due to a 'social order' which subsumes literacy. The same can be said about underdeveloped countries, i.e. lack of development does not emanate from low rates of literacy, but from problems with the social order. This can be supported by the existence of underdeveloped countries with high rates of literacy. In most Middle Eastern countries, for instance, most people are highly educated, yet these countries lag behind in social and economic development. It would be interesting to problematise what Brian calls 'social order', which could probably include social and religious beliefs, as indicated in his conversation with Adam Lefstein (Street \& Lefstein, 2007):

\begin{abstract}
Okay, but what I'm thinking is, how about Persia, Achaemenid Empire, fifth century BC, there's certainly some literacy there, there's huge amounts of iconography, and there's lots of other stuff going on, they're ruling the world. Now, that was two and a half millennia before this European stuff. And they seem to be doing all the things that are in here, cognitive and social activities, participating actively in community, hermeneutics, text treated as significant, working agreement on appropriate or valid interpretation. That's how that community operated, literacy is in there. But, would he say, 'Oh, it's the literacy that's done all that, rather than the politics or whatever, or the theology, the Zoroastrian kind of character of it all.' You know, they freed the Jews from Babylon, you know, they were early democrats, perhaps more so than current world powers. I get quite carried away with that (Street \& Lefstein, 2007, p. 138).
\end{abstract}

Almost all references to Brian's work highlight his distinction between the autonomous and ideological models of literacy, often boiling down to one core concept, i.e. literacy is embedded in social and power relations and is therefore ideological. I would argue that the implication of this core concept is that the social order is in fact the main culprit for social development or lack of it, as more clearly stated by Brian in his later works. This, I believe, forms a legitimate extension of Brian's work on literacy.

\title{
Conclusion
}

Brian's $4^{\text {th }}$ memorial event was a great opportunity to revisit and celebrate Brian's work on literacy. We were enlightened on how Brian's theories have been applied in different parts of the world, but more importantly, this event provided us with the opportunity to explore other dimensions of his work that are still valid and require further research and analysis. As I have argued in this manuscript, more work on 'social order' should be conducted to explore how exactly it relates to literacy. More specifically the following areas can be further explored:

1. What are the core components of social order?

2. How does social order lead to social development or lack of it?

3. Where is literacy situated in social order?

I assume this requires getting even more interdisciplinary and crossing the borderlines of literacy and education, but Brian was always a well-rounded academic, encouraging his students to ask bold question. I believe such extensions of his work indicate that his ideas have withstood the test of time, making his contributions to our social world relevant even today.

\section{Disclosure statement}

No potential conflict of interest was reported by the authors.

\section{References}

Adams, M. J. (1993). Beginning to read: an overview. In R. Beard (ed.), Teaching literacy balancing perspectives (pp. 204-215). London: Hodder and Stoughton.

Bourdieu, P. (1991). Language and symbolic power (G. Raymond \& M. Adamson, Trans.). Cambridge, England: Polity Press. 
Teaching Anthropology 2022, Vol. 11, No. 1, pp. 3640.

Goodman, K. S. (1996). On reading. Portsmouth, NH: Heinemann.

Goody, J. (1977). The domestication of the savage mind. Cambridge: Cambridge University Press.

Scribner, S., and Cole, M. (1978b). Unpackaging literacy. Social Science Information, 17 (1), 19-39.

Street, B.V. (1984). Literacy in Theory and Practice. Cambridge: Cambridge University Press.

Street, B. \& Lefstein, A. (2007). Literacy: An advanced resource book. London and New York: Routledge. 